\title{
Ruchome słowa Roberta Walsera. Analiza związków ruchu, kroków, materialności i słów w „Mikrogramach"
}

Zofia Jakubowicz-Prokop 


\section{Ruchome słowa Roberta Walsera. Analiza związków ruchu, kroków, materialności i słów w Mikrogramach}

Zofia Jakubowicz-Prokop

TEKSTY DRUGIE 2017, NR 4, S. 187-202

DOI: $10.18318 /$ td.2017.4.12

Co w ogóle wiemy o tych nielicznych wśród nas, którzy potrafią we właściwy sposób traktować sprzedajne słowa: nie tak mianowicie jak pismak, który chce je nobilitować i w tym celu „dźwiga” je na swój poziom, ale wykorzystując ich niegodna, niepozorną gotowość na wszystko, aby wydobyć z nich to, co ożywcze, oczyszczające.

Walter Benjamin

W posłowiu do Mikrogramów Roberta Walsera Arkadiusz Żychliński i Łukasz Musiał stwierdzają, że dla chociaż częściowego zrozumienia twórczości Roberta Walsera, należy rozszerzyć pojęcie literatury, tak aby objąć nim „aspekty czysto fizyczne”, a więc piszącą rękę, materiał i narzędzie ${ }^{1}$. Na ile jednak można stawiać granicę między tym, co tekstowe (intelektualne, refleksyjne, duchowe), a tym, co materialne? Tekst sam w sobie nosi już

1 R. Walser Mikrogramy, przeł. M. Łukaszewicz, Ł. Musiał, A. Żychliński, Ha!art, Kraków 2013, s. 125.

\section{Zofia Jakubowicz-}

-Prokop - studentka kulturoznawstwa w Instytucie Kultury Polskiej UW. Interesuje się literaturą i tym, co na jej pograniczu, a także nowymi kierunkami w humanistyce, zwłaszcza animal studies. Pisze o kinie niezależnym dla portalu Bad Taste, prowadzi literackiego bloga. Ostatnio opublikowała esej o ogrodach zoologicznych w pracy zbiorowej Zwierzęta, gender i kultura pod redakcją Anny Barcz i Magdaleny Dąbrowskiej. 
znamiona materialności - i z pewnością nie jest to materialność, nad którą można by przejść do porządku dziennego, którą można by zignorować, choćby $\mathrm{z}$ tego prostego powodu, że bez niej nie mielibyśmy nawet dostępu do treści zapisu, sam zapis by nie istniał. Jednak historia literatury przyzwyczaiła nas do lenistwa, słowo literackie rozpatruje się raczej (nie licząc może niektórych przypadków poezji) bez uwzględniania jego rękopiśmiennego charakteru. Stąd być może wynika podstawowy problem w recepcji twórczości Walsera i to prawdopodobnie mieli na myśli autorzy posłowia.

Walserowska materialno-intelektualna trudność bierze się przede wszystkim z jego praktyk twórczych. Podejście Walsera do pisania, mimo że nie brakowało mu perspektywy artystycznej, było bardzo techniczne i, chociaż nie prowadziło do żadnych wymiernych korzyści, niemal pragmatyczne, z czego pisarz zdawał sprawę w jednej ze swoich notatek:

Wiem, że jestem czymś w rodzaju powieściopisarza-rzemieślnika. $\mathrm{Na}$ pewno nie jestem nowelistą. Gdy jestem dobrze usposobiony, to znaczy w dobrym humorze, zszywam, sczepiam, stapiam, dopasowuję, zesztukowuję, skuwam albo zbijam linijki, których treść każdy od razu rozumie. Jeżeliby ktoś miał na to ochotę, może mnie nazwać pisarskim tokarzem. ${ }^{2}$

Pisanie stanowiło więc przede wszystkim mozolną pracę na twórczym materiale, którego źródłem nie były po prostu autorskie refleksje - choć te w narracji dominują - lecz działanie i cielesność języka.

Cielesność jest tu pojęciem umownym, którego używam z braku lepszego określenia. Język Walsera nie jest oczywiście cielesny w dosłownym sensie, lecz otrzymuje materialny ciężar, dzięki któremu staje się niejako autonomicznym bytem; komunikuje nie tylko przez treść, lecz także przez formę. Namacalność i widzialność języka od pewnego momentu zaczęły stanowić fundament twórczości Walsera.,„Język” znów nie jest tu najlepszym określeniem, chodzi raczej o słowo wyjątkowo konkretne, pisane, ujawnione, zmaterializowane, które jednak pozostaje efemerydą i w oka mgnieniu znika, zastąpione przez kolejne, zostawiając po sobie graficzny ślad - na piśmie i w pamięci. Nie ma więc mowy o języku jako umownie zapisywanym systemie znaków, którego nadrzędnym celem jest przekazanie treści, lecz o materiale, który oczywiście coś komunikuje, ale w pierwszej kolejności wyraża sam siebie, mówi przez swoją formę.

Cyt. za: M. Łukaszewicz Robert Walser, Czytelnik, Warszawa 2009, s. 58. 
W 1909 roku, w wieku trzydziestu jeden lat Walser wydał swoją ostatnią powieść, Jakub von Gunten, i od tego czasu przez następne dziesięć lat, pisał przede wszystkim najwyżej kilkustronicowe teksty, utwory prozą, jak sam je nazywał ${ }^{3}$. Jego twórczość z biegiem czasu malała nie tylko objętościowo, zmniejszały się również ambicje narracyjne, znikała akcja i, co chyba najważniejsze, kurczyło się pismo. Walser coraz częściej pisał ołówkiem, uznając, że w przeciwieństwie do pióra to narzędzie daje niezbędną swobodę, która może wyratować go z twórczego kryzysu:

Pewnego dnia mianowicie zauważyłem, że denerwuje mnie sięganie od razu po pióro; aby się uspokoić, wolałem uciec się do metody ołówkowej, co oczywiście oznaczało pójście okrężną drogą, wzmożony wysiłek. Ale ponieważ ten wysiłek wyglądał dla mnie poniekąd jak przyjemność, wydało mi się, że w ten sposób wyzdrowieję. [...] Wydawało mi się między innymi, że ołówkiem będę pracował bardziej marzycielsko, spokojniej, wygodniej, roztropniej, sądziłem, że opisany sposób pracy stanie się dla mnie swoistym szczęściem... ${ }^{4}$

Walser szybko przywiązał się do nowej metody i niedługo później po pióro sięgał tylko wówczas, kiedy przepisywał prozę, by przekazać ją wydawcy. Znakomita jednak część nigdy nie została skopiowana „na czysto”.

Słowa Walsera wskazują nie tylko na poszukiwania własnej drogi twórczej umożliwiającej maksimum ekspresji, lecz także na terapeutyczny wymiar nowej metody. Żmudna, mechaniczna czynność zapisywania towarzysząca nauce pisania "na nowo" ostatecznie okazała się lekarstwem na kryzys. Powtarzalność i związany z nią wysiłek pozwoliły wprowadzić strukturę, regularny i przewidywalny tryb pracy działający uspokajająco za sprawą jego automatyczności. Technika, która posłużyła później twórcy do zapisywania mikronarracji, stanowiła przede wszystkim zajęcie odciągające od niepokojów i dystrakcji, monotonne, a przez to relaksujące i łagodzące znerwicowany umysł. Była to czynność wydobywająca techniczny wymiar pisania, pozostawała więc bardziej odtwórcza niż artystyczna, co pobrzmiewa w samych

3 W 1919 roku Walser napisał kolejną powieść, Tabolda, która została odrzucona przez wydawcę i zniszczona lub zagubiona. Podobny los spotkał Theodora (1921), który zaginął w jednym z wydawnictw. Ostatnią książkę, napisaną w 1925 roku, Der Räuber, przygotowano do druku dopiero w drugiej połowie XX wieku. 
mikrogramach, które są z jednej strony krótką formą literacką, z drugiej zaś przypominają automatyczny zapis bieżących przeżyć; wydają się raczej strumieniem świadomości, potokiem słów i koncepcji układających się w rytmie codziennych czynności i spacerowych kroków. Techniczność obranej przez Walsera metody zdaje się mieć w sobie trochę z ręcznych robótek, a trochę $\mathrm{z}$ urzędniczego przepisywania, pracy w bliskiej perspektywie bezcelowej, ale rytmicznie kojącej. Kiedy jednak metoda ołówkowa została opanowana, a nauka pisania skończona, do mechanicznej i błogiej codzienności zaczął wkradać się pisarski niepokój, odbierając technice jej czystość, naznaczając ją przymusem kreowania.

W latach 1924-1933 powstało pięćset dwadzieścia sześć mikrogramów, tekstów zapisanych bardzo drobnymi literami na małych kawałkach papieru - na kartkach z kalendarzy, reklamach, rachunkach, kwitach, kopertach, czasem nawet na listach:

Początkowo uważano bruliony za rodzaj prywatnego szyfru graficznego. Potem badania wykazały, że chodzi o swoiście zminiaturyzowaną niemiecką kaligrafię, gdzie ponadto niektóre litery zlewają się ze sobą albo zostają w ogóle pominięte - odczytanie nastręcza ogromnych trudności. Wysokość literek wynosi tu około dwóch milimetrów, karty wyglądają jak nieregularne szachownice, gdzie na każdym polu zapisano tekst prozą, urywek dramatyczny albo wiersz - jedna karta mieści często kilka utworów całkiem odmiennych gatunków. Linijki są równiutkie, pismo bardzo staranne, układ zazębiających się ze sobą tekstów wydaje się dziełem genialnego metrampaża - owe mikrogramy są swego rodzaju kaligramami. ${ }^{5}$

Pisanie jest więc w równym stopniu czynnością intelektualną, za którą zwykło się je uważać, i czynnością techniczną. Nie sposób zrozumieć mikrogramów, nie uświadamiając sobie ich materialności. Nawet „przetłumaczenie" lwiej części miniaturowej prozy wymagało dodatkowo specjalnych narzędzi ${ }^{6}$. Swój specyficzny sposób pisania Walser nazywał metodą, systemem czy obszarem ołówka. W tym wypadku pisanie nie jest po prostu

5 Tamże, s. 11-12.

6 Nazwę wymyślił w 1972 roku Jochen Greven, który jako pierwszy odczytał pismo Walsera i wydał ostatnią jego książkę, Der Räuber. Między 1981 a 2000 rokiem odcyfrowano resztę, przy użyciu specjalnie obmyślonego sprzętu opierającego się na lupie włókienniczej (R. Walser Mikrogramy, s. 127). 
uzewnętrznianiem procesu twórczego, lecz projektowaniem określonej struktury, która może podeprzeć i pogłębić znaczenia.

Walser wydobywał z pisma jego aspekt graficzny, ale była to graficzność szczególna, ponieważ na jej rzecz pisarz zrezygnował z pięknego charakteru pisma, które na pierwszy rzut oka mogłoby wydawać się bardziej „, artystyczne". Trudny do zrozumienia i odczytania "szyfr" uprzestrzennia sam przekaz, rozkłada go na białej kartce w sposób zaburzony, zdegradowany względem zwykłego pisma, eksponując odmienność, sugerując, że nie należy czytać go tak, jak inne teksty. Jest swego rodzaju zaszyfrowaną mapą ${ }^{7}$ z którą nie radzili sobie nie tylko pośmiertni wydawcy Walsera, ale i nawet sam autor. Metoda ołówkowa oznacza zminiaturyzowany ruch piszącej ręki, ograniczoność zapisywanej płaszczyzny, a także niesie ze sobą sensy metaforyczne - nawet odcyfrowane mikrogramy pozostają zagadką, między zdaniami i urwanymi wątkami skrywającą jakąś tajemnicę.

Być może spisywana przez Walsera mapa, pokawałkowana i chaotyczna, miała przekraczać językowe granice. Michel de Certeau w Sztukach działania, analizując użycie „zwykłego języka” w ostatnich tekstach Sigmunda Freuda, stwierdza, że w przypadku przełamywania dyskursu, ,istotna jest praca przekraczania, realizowana dzięki przenikaniu zwykłości do istniejących już naukowych obszarów"8. Biorąc pod uwagę treść mikrogramów - niespójną, fragmentaryczną, opowiedzianą jakby mimochodem - można dojść do wniosku, że właśnie wysiłek transgresji jest tu najistotniejszy. Zwyczajny i nietrwały ślad ołówka utrwala słowa, które pojedynczo nie wychodzą poza swoje codzienne zastosowanie, ale połączone przez pisarza zyskują wyjątkowość. . W ten sposób, podobnie jak było w przypadku przełamywania dyskursów u Freuda, zarówno ślad ołówka, jak i zapisany tekst zyskują nową jakość. „Nieważność” ołówka staje się integralną częścią dzieła literackiego, sam utwór natomiast pod wpływem zmiany narzędzia zmienia swój charakter. Zwykłość ołówka przenika przestrzeń literacką, która tym samym zyskuje lekkość narzędzia i otwiera się na nowe formy ekspresji. To nieustanne stawanie się tekstu urywa się, kiedy proces pisania zostaje ukończony. Może nie chodziło więc Walserowi o efekt końcowy, jeśli ostatecznie przepisywał

7 T. Ingold Being Alive. Essays on Movement, Knowledge and Description, Routledge, New York 2011, S. 199-200.

8 M. de Certeau Wynaleźć codzienność. Sztuki działania, przeł. K. Thiel-Jańczuk, Wydawnictwo UJ, Kraków 2008, s. 8.

9 Por. tamże, rozdział Miejsce wspólne: zwykły język, s. 12-14. 
tekst piórem, a o sam ruch ręki i towarzyszący mu wysiłek nierozerwalnie połączone z pracą umysłu.

Walser zdecydował się na ołówek głównie ze względu na uczucia, które towarzyszyły mu podczas używania go. To, co zapisane ołówkiem, wydaje się mniej ważne, bardziej umowne i tymczasowe. Nie niesie ze sobą tej odpowiedzialności, z którą pisarz spotyka się w kontakcie z piórem, nie zakłada powagi i wzniosłości zapisywanych treści. Pozwala na lekkomyślność i bylejakość, gdyż umożliwia potknięcia, błędy, skreślenia bez poważnych konsekwencji; pomyłkę zawsze można zetrzeć i tym samym unieważnić. Jednak ołówek skłonił Walsera do „roztropności”, jakby niecodzienny charakter nowej metody niósł ze sobą innego rodzaju ciężar. Ołówek daje swobodę, ale jednocześnie zobowiązuje. Tim Ingold w jednej ze swoich prac wskazuje na znamienne podobieństwo ołówka i pędzla do kaligrafii, narzędzi tradycyjnie przypisanych raczej rysunkowi niż pismu. Dlatego też kaligraf może posługiwać się swoim narzędziem w sposób, który jest niedostępny, jeśli używa się stalówki pióra sztywno unieruchomionej w obsadce, ale staje się bardziej możliwe w przypadku ołówka. Jako podstawowe narzędzie rysowania w tradycji zachodniej ołówek dopuszcza znacznie większy stopień elastyczności niż pióro i jest pod tym względem podobny do pędzla ${ }^{10}$. Elastyczność właściwa końcówce pędzla i grafitowi, jak tłumaczy Ingold, dowartościowuje gest i ruch całego ciała, zaangażowanego w pracę nad rysunkiem. Nawet jeśli pędzel czy ołówek wykorzystuje się do pisania, powstały w ten sposób przekaz nie jest tylko zapisem jakiejś językowej treści. Wysiłek kaligrafa, podobnie jak rysownika, koncentruje się na ekspresji, odsuwając kwestię komunikatu na dalszy plan; długość, szerokość czy wyrazistość każdej linii mają znaczenie. Tym samym pisarz intencjonalnie korzystający z ołówka jest jak nigdy dotąd zaprzątnięty formą i materiałem, w którym pracuje. Akcent zostaje przeniesiony z treści na samą jakość wizualną przekazu. W ślad ołówka wpisane są lekkość i beztroska, tak ważne dla austriackiego pisarza, ale ruch pozostawiający go na papierze musi być przemyślany, nawet jeśli niepowodzenie miałoby zostać starte z kartki. To paradoks, widoczny tak dobrze w prozie Walsera, która również wydaje się niepoważna, ale stanowi o egzystencji autora. Walser w mikrogramach spisuje, notuje i przytacza, lekceważąc spójność i logikę narracji, skupia się na drobnostkach, szczegółach i efemerydach, szukając drogi, która mogłaby oddać ich najgłębszą istotę, zdając sobie jednocześnie sprawę, że pisanie jest dla niego najważniejszą praktyką. 
Być może nie chodzi tu wcale o mapę. Są one przecież tworzone, by je odczytywać i podążać według wytyczanych przez nie szlaków. Mikrogramy przypominają raczej szkice, tworzone dla samego aktu tworzenia, pisane z założeniem niedoskonałości. Walser nigdy ich nie poprawiał, nie kreślił ani nie pisał od nowa, ponieważ jego twórczość nie aspirowała do miana wielkiej literatury; jego "próby literackie” przypominają trochę produkt uboczny rozmyślań, spacerów, siedzenia w kawiarni, a więc codzienności w ogóle. Pisanie musiało być stałym elementem życia, niekoniecznie obarczonym powagą pracy zarobkowej, dla Walsera równie naturalnym, co chodzenie. Mikrogramy są raczej zapisem ciągłego ruchu - ruchu kontrolowanego wprawdzie poprzez specyficzną formę zapisu, wciąż jednak spontanicznego, czemu na poziomie technicznym odpowiada właśnie użycie niezobowiązującego ołówka, który pozostawia zapis otwartym na zmiany, przemieszczenia, modyfikacje.

Część wspomnianej już książki de Certeau poświęca związkom między chodzeniem, pieszym przemierzaniem miejskich przestrzeni, a wypowiadaniem, analizując przede wszystkim akty mowy. Jednak konstrukcja mikrogramów pozwala mi na rozciągnięcie tej teorii również na szczególne teksty Walsera. W krótkich utworach pisarza niemal zawsze mamy do czynienia z narracją pierwszoosobową, a jeśli tak nie jest, to narrator w jakiś sposób ujawnia swoją obecność (przykładem może być Swego rodzaju Kleopatra") i w prawie każdym przypadku pojawia się fatyczna funkcja języka, dająca nam pozór obcowania z żywą mową. Wielokrotne zwroty nawiązujące kontakt, pojawienie się drugiej osoby, powtórzenia i inne struktury typowe dla wypowiedzi ustnych są analogiczne, jak pisze de Certeau, do „fatyczności” chodzenia, a więc do kroków nawiązujących kontakt z płaszczyzną i otwierających na komunikację z przestrzenią wokół. W obu przypadkach mamy do czynienia z konkretną teraźniejszością, która staje się najważniejszym punktem odniesienia. Dla Walsera „teraz” odgrywa równie kluczową rolę (także dlatego nie możemy mówić o mapie, która jest wyraźnie rozpięta między przeszłością a przyszłością). Jak wykazałam wcześniej, komunikacja z czytelnikiem w tekstach Walsera pełni funkcje drugorzędne, jeśli w ogóle ma znaczenie. Fatyczność w mikrogramach nie wydaje się służyć nawiązywaniu kontaktu z rozmówcą/odbiorcą (biorąc pod uwagę choćby samą metodę ołówkową, utrudniającą zrozumienie przed przepisaniem tekstu na czysto); pełni raczej funkcję naśladowania żywej mowy, która wyraża ruch, w przeciwieństwie do tradycyjnie rozumianego tekstu. Podobne zwroty nadają prozie 
większą płynność i rytm. Dla Walsera ruch podczas spaceru i ruch pisania są tym samym, wyrażają się więc w analogicznym rytmie. Czas przeszły nie funkcjonuje tak, jak w klasycznej fikcji literackiej, a jeśli w ogóle się pojawia, to jedynie w postaci zapośredniczonej, w historiach opowiadanych przez narratora, który wciąż pozostaje mocno osadzony w „tu i teraz". Opowiada on niejako z perspektywy spacerowicza, któremu mijane widoki przypominają minione wydarzenia. Czas przemija o tyle, o ile zmienia się krajobraz. Opowieści zostają zwerbalizowane, ale mimochodem, urywają się, nie mając końca ani większego znaczenia dla teraźniejszości.

Historie opowiedziane w czasie przeszłym znikają w natłoku spontanicznych, nagłych refleksji. To, co obecne, okazuje się najciekawsze, ponieważ dostarcza najwięcej bodźców, prowokuje skojarzenia i wędrówki po obszarach wyobraźni i krótkotrwałe pomysły zainspirowane ruchem. Podobnie jak poeta, „chodzący przekształca każdy przestrzenny signifiant w coś innego”12 i „,tworzy w ten sposób nieciągłość, albo dokonując wyboru pośród signifiants języka przestrzennego, albo zmieniając owe signifiants przez użytek, jaki z nich czyni”'13. Wcześniej de Certeau pisze:

Historię owej mowy rozpoczyna się tuż przy ziemi, od kroków. Są one liczbą, lecz niebędącą ciągiem. Nie można tej liczby porachować, ponieważ każda z jej jednostek należy do porządku jakościowego: to styl pojmowania i zawłaszczania przez dotyk i ruch. Roją się jako niezliczoność pojedynczości. Gry kroków kształtują przestrzeń. Stanowią osnowę miejsc. [...] Nigdzie się nie sytuują - to właśnie one uprzestrzenniają. ${ }^{14}$

Słowo zapisywane przez Walsera na bieżąco, samo w sobie nie ma konkretnych znaczeń. Ma sens, o ile ujmie się je w ramy ruchu, o ile spojrzy się na nie jako przejaw działania w przestrzeni - realnej i literackiej. Jest symbolem zmiany i wyboru, dokonujących się tu i teraz, ni stąd, ni zowąd, czasem szybko, czasem powoli, nieustannie. Nawet jeśli Walser poświęca któryś z tekstów konkretnej opowiastce, istnieje ryzyko, że w każdej chwili może porzucić lub gwałtownie zmienić wątek. W Jesieni (II) historia duchowego żebraka nagle się urywa i zamiast zakończenia dostajemy informację: „W mieście, w którym

M. de Certeau Wynaleźć codzienność..., s. 99-100.

13 Tamże, s. 100. 
mieszkam, zorganizowano obecnie wystawę obrazów van Gogha"15. Podobnie dzieje się w Samemu tańczyć zabronitem sobie - narracja pod koniec rozpędza się, szybko zmienia przedmiot zainteresowania, by ostatecznie zatrzymać się bez uprzedzenia i unieważnić całą dotychczasową opowieść:

Czy tancerze nie są szczęśliwi i czy w szczęściu nie szukamy tylko uproszczenia, wprawdzie nigdy się do tego nie przyznając, bo próżność nie lubi się do niczego przyznawać, co może nie jest szczególnie inteligentne. Taniec to może wybawienie od masy inteligentnych spraw. Czyż jako intelektualista nie powinienem świetnie o tym wiedzieć? O parkiecie wolno sądzić albo mniemać, że jest dość gładki, by po nim sunąć posuwiście, a jednak nie tak gładki, by nie dało się postawić stopy. Zazdrościłem ujmującym partnerom, że muszą wpierw ukłonić się partnerce z żywością, która robi na mnie wrażenie dopuszczalnej. Jak ja dbam, by czytelnicy bez trudu mnie zrozumieli, jak słodko pachniał przewyborny wdzięk dziewcząt. Powabność przywodzi do ozdobności, natura do sztuki, i nie zazdroszczę doprawdy temu, kto obrazowi, który się tu tanecznie prezentuje, ośmieliłby się cokolwiek zarzucić, a gratuluję każdemu, kto bez zastrzeżeń zgodzi się z powyższym. Gotów byłbym skłonić się do poglądu, że zgoda to majątek. Ale zrobiło się już późno. Idę do domu. ${ }^{16}$

Linearność narracji zostaje rozsadzona, ciągłość zostaje zerwana. „Wobec bezwładu rzeczywistości artysta uprawiający sztukę nasuwa obraz ruchu, spontaniczności, zmienności, gry"17, co wydaje się jedynym rozwiązaniem, jeśli jako pisarz chce się pisać o świecie, którego z zasady nie da się opisać. Pisanie staje się tu działaniem podtrzymującym relację jednostki ze światem, gestem, który nie służy wyjaśnianiu rzeczywistości, nie próbuje jej sobie podporząadkować, ale sam jej ulega.

Zmiana, ruch i przejściowość były dla Roberta Walsera podstawowymi wyznacznikami życia. Stanowiska głównie o niskim statusie, nigdy niezwiązane z literaturą, zmieniał szybko, szybko też się przeprowadzał. Do 1929 roku piętnaście razy przenosił się z miasta do miasta, mieszkał w dwunastu różnych miejscowościach, a podczas trzech pobytów w Szwajcarii miał łącznie

R. Walser Mikrogramy, s. 72.

16 Tamże, s. 100-101.

17 M. Łukaszewicz Robert Walser, s. 77. 
siedemnaście adresów. Nigdy nie miał własnego domu, zamieszkiwane przez niego wnętrza były raczej puste, nienaznaczone prywatnym życiem. Robert Walser większość wolnego czasu spędzał na pieszych przechadzkach, spacerach i wędrówkach, co w sposób znaczący przekładało się na jego twórczość. Niemal w każdym mikrogramie pojawia się czynnossć chodzenia, a większość bohaterów to różnego rodzaju podróżnicy, spacerowicze i wędrowcy. Spacer, podobnie jak metoda ołówkowa, sygnalizuje swobodę - zwalnia z obowiązków, uchyla władzę konwenansów i rygorów codzienności, a więc jest być może jedyną szansą na wolność. Piękno, dobro i przyjemność zależą tylko od aktywności podmiotu ${ }^{18}$. O ile narrator mikrogramów pozostaje w ruchu, o tyle dostrzega urodę otaczającego świata, zachwyca się nią, jest pełen energii i zdolności tworzenia; jeśli jednak zatrzymuje się z niezależnych od siebie powodów, dopadają go melancholia i stagnacja zapowiadające zbliżającą się apatię.

Skojarzenie z flâneurem nasuwa się samo. Benjaminowska figura spacerującego artysty-estety, który przechadza się powoli po ulicach miasta i napawa się widokami będącymi dla niego źródłem „radosnego podniecenia”, ma niewątpliwie wiele wspólnego ze spacerującym narratorem mikrogramów. Aktywność flâneura jest ściśle powiązana z refleksją przetwarzającą przestrzeń w metafory i sny. „Anamnetyczne upojenie, w którym flâneur wędruje po mieście, karmi się nie tylko podsuwaną mu zewsząd naocznością, lecz często przyswaja sobie, jak coś przeżytego i doświadczonego, zwykłą wie$\mathrm{dzę,} \mathrm{ba,} \mathrm{nawet} \mathrm{martwe} \mathrm{dane"19.} \mathrm{Następuje} \mathrm{narkotyczne} \mathrm{wymieszanie} \mathrm{tego,} \mathrm{co}$ wyobrażone, zasłyszane, wspomniane; miejskie mity i opowieści łączą się z faktami i obserwacjami. Wszystko wydaje się w jakimś sensie podobne, wszystko nakłada się na siebie, wszystko ma „twarz"20, zyskuje własne życie, podmiotowość. Rzeczywiście, w toku narracji wszystko zdaje się manifestować swoją żywotność, siłę, która nie jest jednak przypisana do jednej osoby, przedmiotu czy pojęcia, lecz łączy je wszystkie. Pojęcia, będące zarazem bohaterami, płynnie zmieniają swój stan, ujawniając tym samym językowe i emocjonalne aporie: szczęście swobodnie transformuje się w nieszczęście (To znowu była książka), stosowność w niestosowność (Trzy tragiczne historie), powodzenie prowokuje niepowodzenie (Książki mogą mieć niepowodzenie):

18

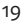

20

Tamże, s. 63.

W. Benjamin Pasaże, przeł. I. Kania, Wydawnictwo Literackie, Warszawa 2006, s. 462.

Tamże, s. 463. 
Kobieta, u której popadłem w niełaskę, znalazła za to u mnie łaskę, to znaczy w bród uznania, ponieważ zdawała się potrafić wzbudzić we mnie pewne poruszenie. Ona, która znalazła mnie pozbawionym uroku, wydała mi się pod każdym względem urocza, piękna, pociągająca i znacząca. Miałem u niej niepowodzenie, ona z kolei zupełnie na próżno starała się o powodzenie u własnego męża, podczas gdy ten pozwolił mi mieć niebagatelne powodzenie u siebie, co znowu skłoniło mnie do tego, aby pozwolić jej cieszyć się powodzeniem u mnie, gdyż po prostu naraz nadzwyczajnie zainteresowałem się ową osobą niemającą powodzenia. Jej doskonały małżonek zainteresował się z kolei moim brakiem powodzenia, które musiało go poruszyć. Jego poruszenie oznaczało dla mnie powodzenie u niego, podczas gdy znów moje przejęcie zaowocowało efektownym powodzeniem u tej, którą mąż jej ukradkiem na moją korzyść, jak sądził, porzucił, aby zdała sobie sprawę, że powodzenia są, ogólnie rzecz biorąc, sprawą nader nieostrożną czy niepewną. ${ }^{21}$

Płynność i tempo zmiany znaczą tu językowy ruch, w którym sensy nieustannie się przenoszą. Prawda znajduje się gdzieś między nimi, przeczuta przez piszącą dłoń, a ołówek, sam w sobie wystarczająco niepewny i podatny na zmiany, okazuje się najbardziej stosownym narzędziem, by ją uchwycić.

Flâneur porusza się wprawdzie po rzeczywistej przestrzeni, ale jego wędrówka nie zakłada materialnego kontaktu z otaczającym światem. To czyste przeżywanie, istotne o tyle, o ile ulega nieprzewidywalnym zmianom i zapomnieniu. Inaczej dzieje się w przypadku Walsera, który ostatecznie postanowił zostawić na papierze ślad po swoim doświadczeniu. Co skłoniło pisarza tak skoncentrowanego na ulotności i ruchu, by sięgnąć po ołówek i zacząć pisać? Czy zapisywanie chwili nie jest czymś zupełnie jej przeciwnym? W przypadku pisarza spacer nie wydaje się efektem niepohamowanego głodu wrażeń charakterystycznego dla flâneura, lecz wyrazem potrzeby regularności i spokoju. Metoda ołówkowa zapewnia również coś, czego flâneur do końca zostaje pozbawiony: punkt zaczepienia w przestrzeni, materialny znak więzi między otoczeniem i spacerowiczem, ustanawiający relacje między tu i tam, między widzianym i zapisanym, między wyobrażonym i materialnym. Flâneur skazany jest na wieczną transformację, nieustanne przeobrażanie się rzeczywistości. Walser, pisząc mikrogramy, kwestionuje postawę charakterystyczną dla Benjaminowskiej figury. Nie sięga po pióro, nie sili się na wyszukaną 
formę, zapisuje wszystko „jak leci”, rezygnuje z powagi długich narracji, ale jednak zapisuje, zostawia rzeczywiste ślady, wyznacza drogę przebytą przez własne myśli. Robi to ołówkiem, trochę mimochodem, jakby nie był do końca pewny słuszności pisania i jakby uznawał obraną przez siebie metodę za jedyny stosowny sposób wchodzenia w językową relację ze światem. Walser był wprawdzie rozmyślającym spacerowiczem, ale przede wszystkim pozostawał pisarzem. Ruch miał być fundamentem egzystencji, ale żeby mógł zostać dopełniony, musiał znaleźć chociaż minimalne odzwierciedlenie w materii, które gwarantował ołówkowy zapis.

Znak wyznaczający przestrzeń i sposób poruszania się po niej jest niewątpliwie związany z mapą. Podobną funkcję pełni język, który nakłada na świat strukturę ustalającą relacje między poszczególnymi jego elementami. Trudno stwierdzić, czy można w przypadku Walsera mówić o mapowaniu czasoprzestrzeni, ponieważ zarówno pismo, jak i język nie wydają się w tym wypadku wystarczająco pewne i spójne. Niewątpliwie mamy jednak do czynienia ze strukturą dążącą do nadania chwiejnej rzeczywistości jakiegoś porządku, co znacząco wiąże się z dążeniem do wyjścia z kryzysu twórczego. Tekst nie służy rozgraniczeniu prawdy i fikcji, ale sygnalizuje zmagania człowieka z materią, którą wprowadza w twór pozornie czysto intelektualny. Jeśli mikrogramy mają coś wspólnego z mapą, jest to mapa zaszyfrowana, prowadząca do tajemnicy. Nie ułatwia w żaden sposób drogi, którą mamy przebyć, zaprzecza więc podstawowej funkcji mapy. Pisarz, zapisując materiał w ten specyficzny sposób, dodatkowo utrudnił jego odbiór. Czytając mikrogramy w odszyfrowanej już formie, ale świadomi przebytej przez pisarza drogi, nie zadajemy sobie pytania o szlaki jego wędrówek, lecz o przyczynę decyzji podjętych przez niego na trasie. W odczytanych i przepisanych utworach dostajemy pozornie rozwikłaną zagadkę, ale wcale nie włożono nam rozwiązania do ręki, ponieważ ono znajduje się w samym procesie kodowania rzeczywistości, w metodzie ołówkowej i w zmaganiach z materią pisma.

Tim Ingold stwierdza, że krajobraz i jego użytkownik kształtują się wzajemnie, wnikając w siebie, a „tu" $i$ „tam" błyskawicznie przestają być rozróżnialne. Michel de Certeau uznaje z kolei, że przestrzeń kształtuje się i jest wypowiadana przez pieszego na zasadzie ustalania tego, co "tu" i ,tam", przez wyznaczanie granic i stwierdzanie łącznych i rozłącznych relacji między poszczególnymi miejscami. Jestestwo spacerującego realizuje się w „sposobach przechodzenia do innego"22, w ustalaniu podziałów, przemierzaniu ich 
i zawłaszczaniu krokami tego, co obce, przy jednoczesnym uwewnętrznieniu tej obcości. Wykazuje dalej analogię między chodzeniem a pisaniem, uznając literaturę również za praktykę przestrzenną ${ }^{23}$. UWalsera ta przestrzenna gra wydaje się wszechobecna: poszczególne elementy narracji płynnie w siebie przechodzą niezależnie od łączących je związków. To, co było opowiadane, traci zaraz znaczenie na rzecz tego, co dzieje się teraz lub co ma zaraz nastąpić. Zawłaszczanie zachodzi podczas zapisywania, a uwewnętrznienie dokonuje się poprzez metodę ołówkową - wynalezioną i wyuczoną od zera, swoją, ale podległą niekontrolowanej rzeczywistości, bo przez nią ostatecznie determinowaną.

Dialektyka „swój - obcy” realizuje się również w sferze „rzeczywiste wyobrażone", której Walserowski człowiek do pewnego stopnia również próbuje wyznaczyć granice - te pozostają jednak wątłe i chwiejne, załamują się i zanikają. Nawet kiedy narrator mikrogramów zaznacza, czy opowiada historię zasłyszaną, przeżytą czy wymyśloną, i tak do końca nie wiemy, jaki jest jej status. Na ile można ufać fikcji-nie-fikcji literackiej, która przecież tak bardzo w przypadku Walsera sprzężona jest z biografią autora? Nigdy nie jesteśmy w stanie tego stwierdzić. Ta strategia literacka przypomina jednak bardziej zabawę niż fatalny obowiązek. Jest grą między tym, co rzeczywiste, i tym, co możliwe. Z tej gry bierze się „szczęście, doznanie błogiego spokoju i harmonii", ponieważ gra jest również przejawem upragnionego, życiodajnego ruchu. „Codzienność jak gdyby nie istnieje, ale jak gdyby istnieje. Spacer nie byłby tym, czym jest, gdyby nie był wpisany w horyzont tamtego, odrzuconego porządku"24, porządku codzienności, konwenansów i społecznych powiązań, a więc gdyby nie wyobrażał tego, co możliwe. Tym samym dochodzimy do kolejnego paradoksu. Czy działanie jest wartościowane względem tego, czego nie ma? Jakflâneur przemieszcza się w imię tego, co było, tak spacerujący Walser żyje podług tego, co mogłoby być?

23 „Przestrzeń byłaby dla miejsca tym, czym staje się słowo w chwili, gdy jest wypowiadane, to znaczy pochwycone w niepewności urzeczywistniania, przemienione w określenie będące wynikiem rozmaitych konwencji, rozumiane jako akt jakiejś teraźniejszości (albo jakiegoś czasu) oraz zmodyfikowane w wyniku pojawiania się kolejnych układów. W odróżnieniu od miejsca, przestrzeń jest pozbawiona jednoznaczności oraz stabilności «własnego»" (tamże, s. 117) i dalej: „Dynamika opowieści wynika ze sprzeczności, jaką wyobraża stosunek między granicą a mostem, to znaczy między jakąś przestrzenią (usankcjonowaną) a jej zewnętrznością (obcą)" (tamże, s. 125). 
Żywiołem flâneura jest nie tylko otwarta przestrzeń miejska, lecz także ludzka masa, która ją wypełnia. Flâneur pozostaje jednak indywidualny i jednostkowy, przez co otaczający go ludzie mają zupełnie inny status, status tłumu właśnie, który staje się raczej obiektem obserwacji niż współużytkownikiem przestrzeni, przez co częściowo traci swoją podmiotowość. Mimo nieustającego wrażenia bycia na widoku, bycia widzianym i obserwowanym, flâneur pozostaje „całkowicie nie do wyśledzenia”. W ten sposób udaje mu się zachować granicę między sobą a innymi. Podobne tendencje można dostrzec u Walsera:

Samotność i życie na marginesie mają tu, wobec urody świata, stanowczo inne znaczenie [...]. Nie są elementami losu biednych ludzi ani produktem absurdalnego porządku społecznego, ale warunkiem wspaniałych przeżyć, sytuacją świadomie i z własnej woli wybraną dla przywilejów, jakie zapewnia. Samotność nie tylko nie jest tu wygnaniem poza obręb zbiorowości, nie tylko niczego nas nie pozbawia, ale przeciwnie, oferuje możliwości, które życie wśród ludzi skutecznie dławi. ${ }^{25}$

Jest to więc życie z ludźmi poza ludźmi, którzy należą jakby do innej rzeczywistości - do innej, ale jednak w jakiś sposób przenikają do świata pisarza. W mikrogramach nie da się wskazać jednoznacznego podziału między narratorem a pozostałymi bohaterami. Osoba mówiąca raz zaznacza swoją (aktywną) obecność w świecie przedstawionym, raz opowiada z dystansu, który oddziela ją od opisywanych zdarzeń. Co więcej, często nawet nie jesteśmy w stanie wskazać, kto jest kim. Nie wiadomo, gdzie dokładnie przebiegają granice między ja-ty-on-ona-my-wy. Ponadto sam narrator przejawia nieustannie skłonności do zwielokrotniania samego siebie, do rozpleniania się na wiele podmiotów. Do podobnego rozdwojenia osobowości dochodzi np. w Miarka wkrótce się przebierze: „Tylko jemu przyszło to do głowy, temu Jemu wewnątrz mnie, temu posiadaczowi pomysłów, którego w sobie trzymam. Zapewniam was, że osobiście, z własnego porywu nigdy prawie bym się nie śmiał. To on wciąż pęka ze śmiechu, bajeczny gość"26.

Nie chodzi tu jednak tylko o narratora. Czasem składniowy chaos powoduje zlanie się wszystkich podmiotów ze sobą. Nie wiemy już wtedy, kto co robi ani kto co mówi, ani tym bardziej właśnie, kto jest kim. Nie wiemy 
nawet, czy chodzi o ludzi, zjawiska, uczucia, wrażenia czy przedmioty, ponieważ u Walsera wszystko zyskuje własną podmiotowość i równy status.

W 1929 roku Robert Walser trafił do zakładu leczniczego w Waldau, gdzie stwierdzono u niego schizofrenię. Dręczyły go ostre stany lękowe, niepokój, halucynacje i głosy wytykające mu lenistwo. Chociaż pisarz utrzymywał, że w zamknięciu nie może pisać, a jego stany lękowe są wynikiem kryzysu twórczego i nieustannego przebywania z samym sobą, w Waldau napisał jeszcze sporo utworów prozą. W jednej z notatek zanotował: „Jest nonsensem i prostactwem wymagać ode mnie, żebym pisał w zakładzie. Jedyną glebą, na której poeta może tworzyć, jest wolność"27. Przestał pisać dopiero po przeniesieniu do zakładu w Herisau, gdzie spędził ostatnie dwadzieścia trzy lata życia. Jego jedyną rozrywką pozostały wówczas niedzielne spacery, które nie symbolizowały już jednak swobody, raczej znaczyły świadomość zniewolenia. Martin Walser pisał o swoim bracie:

jego nieśmiałość i dzikość szuka po prostu materiału, w którym mogłaby się wyrazić, ale nie chce się sama rozpoznać w żadnym trwałym kształcie. Tego rzeczywiście się bał. Unikał niepodważalnego obrazu samego siebie, wszystkiego, co stałe, przerażającego skostnienia świadomości, wszystkiego w ogóle, co mogłoby być podstawą ostatecznego osądu. ${ }^{28}$

Ruch był zbawczy również dlatego, że dzięki niemu trudniej jest coś wyraźnie dostrzec. Także ołówkowy zapis nie sprzyja ani ostateczności, ani wyrazistości, przeciwnie, zwłaszcza przy do tego stopnia zminiaturyzowanym piśmie powoduje, że tekst jest bardziej rozmazany i niemal niemożliwy do rozpoznania. Metoda ołówkowa nie tylko dawała wolność, lecz także mogła służyć zacieraniu śladów. To, co napisane ołówkiem, może łatwo zniknąć z kartki, może pozostać też niezauważone, ponieważ nie jest przecież tak ważne, tak fundujące i tak trwałe, jak to, co napisane tuszem. Z tym samym wiąże się miniaturyzacja. Niewyraźne, nieczytelne pismo stara się skrywać indywidualność i osobowość, stara się ją „zaszyfrować”, ostatecznie okazuje się to jednak niemożliwe. Metoda ołówkowa jest systemem tak charakterystycznym i oryginalnym, że nie sposób nie odgadnąć jej autora. 


\section{Abstract}

\section{Zofia Jakubowicz-Prokop}

UNIVERSITY OF WARSAW

Robert Walser's Movable Words: Relationships of Motion, Steps, Materiality and Words in the Microscripts

Jakubowicz-Prokop examines how material and tools influence literary content inscription. The example of Robert Walser's Microscripts - a collection of short prose pieces written on scraps of paper, remarkable for their tiny script in pencil - suggests how the very inscription of a text shapes its form and what a significant impact the means of inscription has on the content conveyed by that form. Thanks to this, the text becomes a spatial phenomenon, it gains material weight. The text is the effect not only of intellectual but also of physical labour. Building on the theories of Michel de Certeau and Tim Ingold, Jakubowicz-Prokop demonstrates that the meaning of Walser's texts is realized in the tension between thinking and acting as well as between art and technology.

\section{Keywords}

Robert Walser, the materiality of writing, pencil method, handwriting, Microscripts 